\title{
Forests expand as livestock pressure declines in subtropical South America
}

\author{
Rafael E. Bernardi $^{1,2,3}$, Marion Buddeberg $^{1}$, Matías Arim $^{3}$ and Milena Holmgren $^{1}$
}

\begin{abstract}
Forests, savannas, and grasslands are prevalent across the landscapes of South America. Land uses associated with these ecosystems have influenced economies from household to country scales, shaping social-ecological organization across the region since pre-Hispanic societies. Recent studies suggest that tropical and subtropical grasslands, savannas, and forests represent alternative ecosystem states. Transitions between these ecosystem states can be promoted by changes in disturbance regimes and by land uses determined by the organization of societies and their activities. We analyzed how changes in agriculture, fire, and livestock management influenced forest cover over a 45-year span (1966-2011) in the Campos region, an extensive subtropical ecotone between rain forests and grasslands of South America. We found that forests contracted in areas with high crop agriculture, whereas forests increased in those grasslands where livestock densities had been reduced. These patterns were strongly associated with soil and topographic conditions because they broadly determine the potential land productivity and use. Our results show that current land use and disturbance regimes explain the large extent of grasslands across the South American Campos and suggest that changes in land use and disturbance regimes could facilitate or prevent transitions between subtropical forests, savannas, and grasslands altering the provision of ecosystem services linked to them.
\end{abstract}

Key Words: agriculture; Campos; cattle; ecological transitions; ecosystem services; grasslands; sheep; tree cover; Uruguay; vegetation shifts

\section{INTRODUCTION}

The global distribution of forests, savannas, and grasslands has been studied since the first observations by early naturalists that related vegetation structure and composition to local environmental conditions (Darwin 1890, Von Humboldt and Bonpland 2009/1807). Tree cover increases from grasslands to forests as climates become moister and warmer to facilitate tree growth. However, the probability of finding grasslands, savannas, or forests in any particular place results from the complex interplay of resource conditions, land use, and disturbance regimes. Indeed, across the tropics and subtropics, fire occurrence and herbivory can maintain open grasslands and savannas in regions with enough precipitation to support closed-canopy forests (Hirota et al. 2011, Staver et al. 2011, Lehmann et al. 2014, Dantas et al. 2016, Staal et al. 2018, Bernardi et al. 2019). Forests, savannas, and grasslands provide different types of environmental services and configure cultural views that strongly influence economic activities and social organization (Berkes et al. 2000, Millennium Ecosystem Assessment 2005). In turn, socioeconomic activities are associated with land uses that can shape ecosystems and landscapes (Foley et al. 2005, Millennium Ecosystem Assessment 2005, Aleman et al. 2016).

In South America, forest loss resulting from land conversion to agriculture has been significant (Boletta et al. 2006, Ribeiro et al. 2009, Redo et al. 2013, González-Roglich et al. 2015). Croplands tend to occupy the more fertile soils, and their expansion at the expense of forests can be linked to global and local drivers such as demands from international markets and local agricultural practices (Geist and Lambin 2002, Richards et al. 2012). Tree expansion into grasslands has also been observed in South America (Gautreau 2010, Chaneton et al. 2012, Müller et al. 2012, González-Roglich et al. 2015) and correlated to land uses and disturbance regimes (Chaneton et al. 2012, Müller et al. 2012, Blanco et al. 2014, Bernardi et al. 2016b, Brazeiro et al. 2018). Although the transition from forests to grasslands as a direct consequence of agricultural spreading has been fairly well established (Paruelo et al. 2006, Vega et al. 2009), the net result of this process with the opposite trajectory of tree expansion into grasslands remains less well understood, despite the major ecological and economic consequences. We echo the call for assessing changes in forest cover spanning large temporal periods and scales (González-Roglich et al. 2015).

The Campos grasslands are an ecotone between the subtropical Atlantic and Araucaria forests of southern Brazil and the temperate grasslands of Argentina. The whole of Uruguay is within this ecoregion. The Campos are mostly covered by grasslands under livestock extensive management and have remarkably low tree cover $(\sim 5 \%)$ for their precipitation levels $(\sim 1200 \mathrm{~mm})$. These ancient, "old-growth" grasslands (Veldman et al. 2015) evolved during drier, colder periods in the Pleistocene that were marked by frequent droughts (Behling et al. 2007, Piovano et al. 2009, Jeske-Pieruschka et al. 2010, del Puerto et al. 2013). During the Holocene, loss of large herbivores and increased fire frequency, possibly associated with the first human settlements, probably occurred across the Campos as has been described for southern Brazil (Behling et al. 2007, Blanco et al. 2014). More recently, since the 17 th century, extensive livestock production expanded to become the dominant land use form across the Campos grasslands. Humans have therefore exerted strong influences through land conversion and the modification of disturbance regimes that can affect forest cover. Recent field experiments and observations indicate that fire and livestock currently limit forest expansion across southeastern South America (Pillar and Quadros 1997, Müller et al. 2012, Blanco et al. 2014, Bernardi et al. 2016b, Etchebarne and Brazeiro 2016, Brazeiro et al. 2018). Indeed, livestock densities in the Campos are among the highest in South America, which may also explain the low fire frequencies of this region (Di Bella et al. 2006, Bernardi et al. 2016b). Understanding how these disturbances can affect vegetation structure is therefore particularly relevant. We

\footnotetext{
${ }^{1}$ Resource Ecology Group, Wageningen University, Wageningen, The Netherlands, ${ }^{2}$ Aquatic Ecology and Water Quality Management Group, Wageningen University, Wageningen, The Netherlands, ${ }^{3}$ Departamento de Ecología y Gestión Ambiental, Centro Universitario Regional Este (CURE), Universidad de la República, Uruguay
} 
analyzed changes in native forest cover over a 45 -year period in Uruguay in relation to fire occurrence, livestock density, agricultural land cover, climate, soils, topography, and road density.

\section{METHODS}

\section{Forest cover and environmental variables}

We analyzed changes in native forest cover for the whole of Uruguay (Fig. 1), in the Campos region of the Rio de la Plata Grasslands (Soriano 1992). Uruguay's native forests have been classified into broad categories based on physiognomic and topographic criteria. Riparian forests are the most abundant type and, like ravine forests, form well-defined strips along watercourses. Hillside forests occur on higher elevations and rocky formations, often forming patches within grasslands. Palm and coastal forests ("Psamófilo") can be found in localized regions (Brussa and Grela 2007). Very small areas of savannas, or "park forests" of Prosopis and Vachellia spp. remain, mostly to the west of the country, having been severely diminished by human activities. We merged Uruguay's forests into a single "forest" category, including its park forests, which occupy a marginal fraction of the overall forest area. Forest cover change was estimated as the difference in forest cover between the forest cartography of the year 2011, based on Landsat images for that year (Ministerio de Ganadería Agricultura y Pesca [MGAP] 2012), and the first hand-drawn forest cartography, based on the interpretation of aerial images taken in 1966/1967 (http://www. sgm.gub.uy/; MGAP 1979).

Scanned images of the first forest cartography were georeferenced and projected onto the Yacaré Global Coordinate System, and the quality was checked when original aerial images were available. We used a semiautomated procedure to convert images into polygons. In the case of the 1966/1967 historical map, we considered a hand-drawing accuracy of $0.5 \mathrm{~mm}$ (Kramer et al. 2011). At a scale of 1:250,000, this translated into an estimated error of $125 \mathrm{~m}$. The root-mean-square error of the georeferencing procedure was estimated as $\sim 40 \mathrm{~m}$ (Iliffe and Lott 2008, Kramer et al. 2011). Distortions in the alignment of the aerial photographs were corrected using local references, although some problems of alignment persisted, particularly in the north of the country, where fewer stable points for the georeferencing were available, because of fewer settlements and roads, and rivers were used. These problems did not affect the total forest cover area. We did not include commercial tree plantations for any year. Analysis was done using the administrative land units of the agricultural census, which are the smallest administrative division with available data of the National Agricultural Census. We considered each agricultural census division as a data point. Land use and environmental variables were averaged within each division. We excluded census units with a surface area below $100 \mathrm{~km}^{2}$ or with urban land cover above $20 \%$ to exclude periurban areas. A total number of 184 units were included in the analysis, with an average area of $850 \mathrm{~km}^{2}$ (standard deviation $\pm 490 \mathrm{~km}^{2}$ ).

We related forest cover change to climate, soil and topography, land use, and disturbance regimes. Climate variables included the mean annual levels of precipitation and temperature, as well as indicators of how they change seasonally and interannually (Hirota et al. 2011, Holmgren et al. 2013). We included the
Fig. 1. Forest cover change in Uruguay (1966-2011) and explanatory drivers. (a) Net forest loss in red and net forest gain in green in a $1-\mathrm{km}^{2}$ raster. Colored regions largely depict forest distribution in Uruguay. (b) Census divisions, used as analysis units. Bottom panels: Generalized linear model of forest cover change (\%) between 1966 and 2011 for Uruguay. Prec., precipitation.

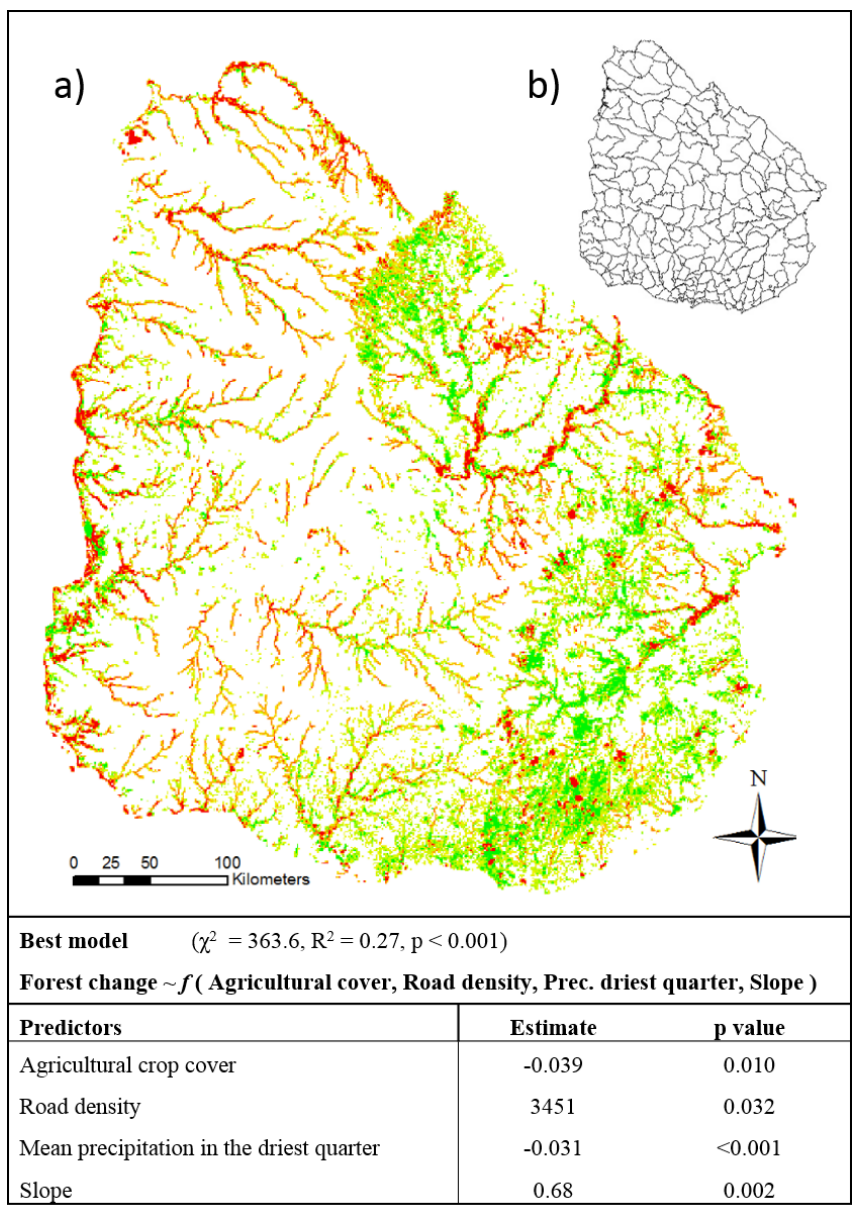

following climate variables as averages for the period 1950-2000 (Hijmans et al. 2005): mean annual precipitation, mean annual temperature, coefficient of variation in precipitation, precipitation of the driest quarter, and temperature of the hottest quarter. We used two widely used national soil indexes: the soil productivity index CONEAT (Duran 1987) and the water holding capacity index (Molfino and Califra 2001). Altitude and slope were obtained from the national database of MGAP (http://www. snia.gub.uy/). Because most forests in Uruguay occur alongside watercourses, we considered river density as a potential explanatory variable (Bernardi et al. 2016b). River density was derived from the HydroSHEDS database (Lehner et al. 2006). We included road density as an explanatory variable because it is strongly associated with population, urban development, and human access to land, which can result in land use change and deforestation (Cai et al. 2013), as well as in the introduction of invasive tree species (Chaneton et al. 2012). The road layer was obtained from the Ministry of Transportation and Public Works 
Fig. 2. Regions of Uruguay. (a) Edapho-topographic regions of Uruguay used in the statistical analysis. Box plots show values of mean annual precipitation (b), agricultural cover (c), livestock density (d), and soil productivity (e) for each region. LU, livestock units.

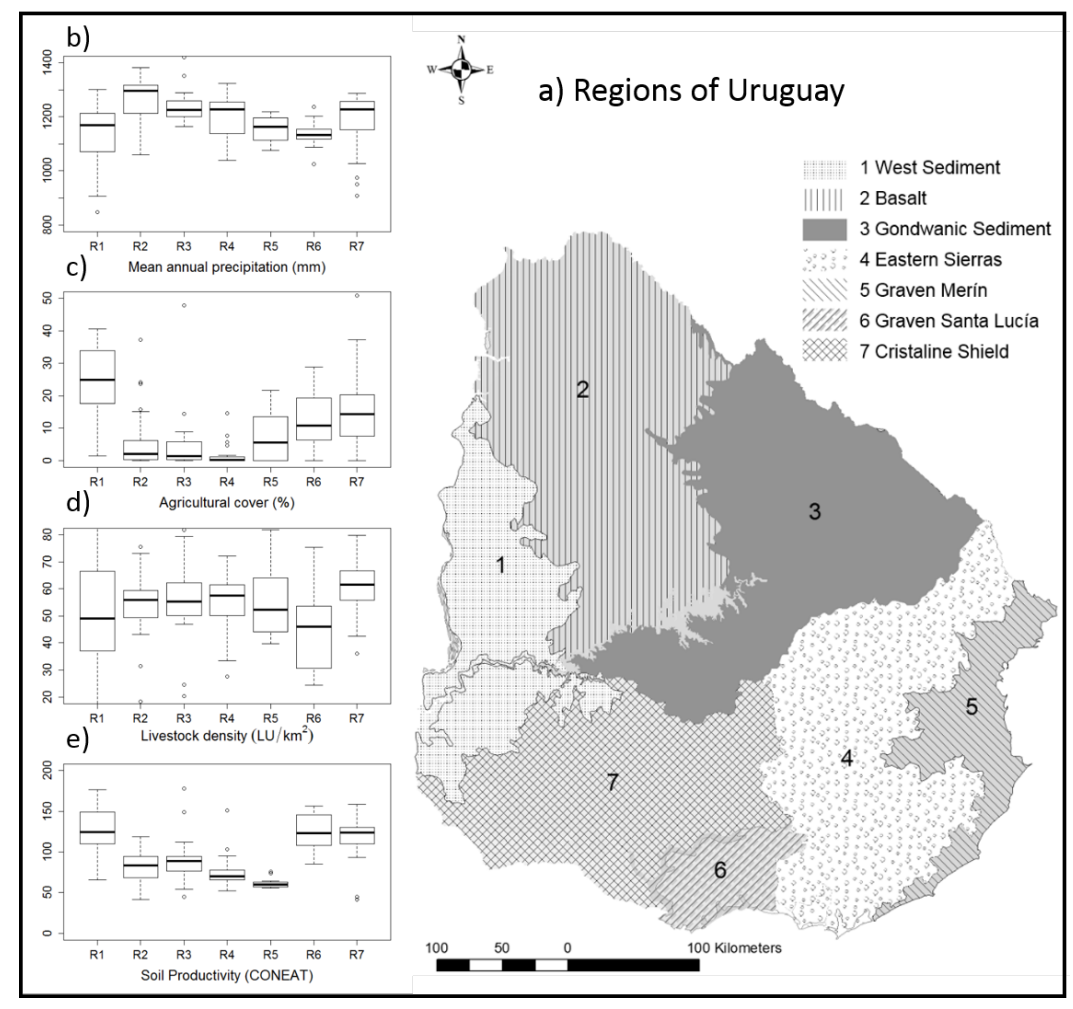

(http://www.snia.gub.uy/), and road density was calculated with the Kernel density function in ArcGIS. Agricultural cover, a main driver of forest loss, was derived from the Land Cover Classification System map (Ministerio de Vivienda, Ordenamiento Territorial y Medio Ambiente; MGAP; and Food and Agriculture Organization of the United Nations 2008) and expressed as a percentage of the area in each census division. Cattle and sheep densities for each census division for the period 2000-2011 were obtained from census data (http://www2.mgap.gub.uy/portal/ page.aspx?2,diea,diea-principal,O,es,0). Livestock values where expressed in livestock units (LU) of $380 \mathrm{~kg}$ equivalent standard weight. General conversion to livestock units for cattle was 0.75 LU/animal, and for sheep, 0.17 LU/animal. Specific conversion factors were used for each development stage of animals when available (Saravia et al. 2011). Average decadal livestock values in the 1996-2011 period were obtained from the National Agricultural Census (http://www2.mgap.gub.uy/portal/page. aspx?2, diea, diea-principal, O,es,0) for the 19 departments of the country and assigned to the census division of each department to obtain changes in livestock densities. Fire frequency was calculated as the number of times a pixel burned over a 10-year period (2000-2009) derived from the MODIS MCD445A1 Burned Areas Monthly product (Roy et al. 2008).

\section{Data analysis}

Biophysical heterogeneity can influence of the patterns of land use in the region (Vega et al. 2009). To capture the main landscape features and their associated vegetation types, we used existing classifications of seven major "edapho-topographic" subregions of the country determined by their general soil and topographic characteristics (Panario 1988, Brazeiro 2015, Modernel et al. 2016; Fig. 2). The census divisions (Fig. 1) were assigned to the subregion that covered most of its surface. These subregions were clustered in two groups with agricultural crop cover above or below the national median value for all subregions $(\sim 5 \%$ of the area). We used $t$ tests to assess forest cover change differences between these two regions with the "t.test" package in R. Low agricultural areas included "Eastern Sierras" hill formations of the east and northeast of the country and the "Gondwanic Sediment" northeastern regions. It also included the "Basalt" region, characterized by shallow soils over a basaltic geologic substrate (Modernel et al. 2016). These regions are predominantly used for extensive livestock grazing and have had less expansion of agriculture because of their relatively less productive soils. High agricultural areas included the more productive soils of the west ("West Sediment") and the south ("Cristaline Shield" and "Graven Santa Lucía"), where most of the crop agriculture is grown, and the plains of the Merín lagoon ("Graven Merín") to the east of the country, which have a high cover of rice agriculture.

To relate forest cover change to explanatory variables (Table A1.1 in Appendix 1) we used generalized linear models. Models were selected using the package "bestglm" in R version 3.2.3 (McLeod and $\mathrm{Xu} 2011$ ) using the Akaike information criterion (Table A1.2 
in Appendix 1). A subset of the best five alternative models was assessed for comparison with the best model using cross validation. The partial contribution of variables in the best models (Table A1.3 in Appendix 1) was assessed with the package "rsq" in R (Zhang 2018). Spatial autocorrelation in the model residuals was assessed using Moran's I. We found weak spatial autocorrelation indicated by rather low Moran's I values (Table A1.2 in Appendix 1). All variables were considered in model construction; highly correlated variables (Pearson $\rho \geq 0.5$ ) were tested independently. Dependent variables in plots were presented as partial residuals to visualize the effect of each single predictor variable (Sibly et al. 2012).

\section{RESULTS AND DISCUSSION}

\section{Four decades of forest cover change}

Our analysis of forest cover change between 1966 and 2011 shows a small increase in native forest cover $(\sim 7 \%)$ over this 45 -year period. This increase is congruent with recent reports of woody plant expansion in the Campos and Pampas (Baldi and Paruelo 2008, Gautreau 2010, Müller et al. 2012) and in other grassdominated systems (Brown and Carter 1998, Bond 2008, Gartzia et al. 2014, Stevens et al. 2017). This limited forest expansion has not occurred across the whole Campos of Uruguay. Increases in forest cover were prevalent in the eastern regions, mostly on hills and coastal plains (Fig. 1). These patterns can indeed be explained by land use and environmental variables (Fig. 1): Change in forest cover was negatively associated with agricultural cover $(p=0.01)$ and positively correlated with slopes $(\mathrm{p}=0.015)$, road density $(\mathrm{p}$ $=0.032)$, and drier climate $(\mathrm{p}<0.001)$. We recorded forest losses across the west and southwest of the country, as well as in the plains of the Merín lagoon to the east. These are regions with extensive agricultural activity where forest cover reductions were likely a result of land conversion to agriculture. Indeed, Uruguay has increased its agricultural crop production during the study period, from roughly 700,000 ha in 1970 to more than 1.7 million in 2010 (MGAP 2011).

Because agricultural crop cover was identified as a main determinant of forest cover change at the country level, we clustered the edapho-topographic regions of Uruguay into two groups with agricultural cover above or below the median country value (Fig. 3). Forest cover change between these 2 groups differed significantly $(\mathrm{t}=2.29, \mathrm{df}=182, \mathrm{p}=0.023)$. In regions with belowmedian agricultural cover, i.e., hills to the east and northeast of the country and the shallow basaltic regions of the northwest, net forest cover increased by $11 \%$ during these 4 decades. This increase was negatively correlated with mean annual precipitation $(\mathrm{p}<$ 0.001 ; Fig. 3b) and positively correlated with slope $(\mathrm{p}<0.001$; Fig. 3c) and reductions in livestock densities ( $<<0.0034$; Fig. 3d). These regions are predominantly used for extensive livestock grazing and have had less expansion of crop agriculture because of their relatively less productive soils. In regions with abovemedian agricultural cover, i.e., the alluvial plains of the Uruguay River and Merín lagoon and the granitic formations at the centersouth regions of the country, forest losses exceeded forests gains (net forest decrease was $1 \%$ ). This forest decline was associated with further increases in agricultural cover $(p=0.0011$; Fig. 3e) and with precipitation in the drier quarter ( $<<0.001$; Fig. 3f).

\section{Drivers of forest cover change}

Distinguishing between regions with agricultural activity above or below the median country values improved our understanding of the drivers associated with forest cover change. In the regions with high agricultural activity, forest decline was likely favored by a drastic expansion of crops and driven by a spike in international prices and new agricultural practices (Vega et al. 2009, MGAP 2011, Modernel et al. 2016). This may have particularly impacted riparian forests, which are the most abundant forest type in Uruguay and are constrained by croplands (Bernardi et al. 2016b).

The increase in forest cover in the northeastern areas with steeper slopes was significantly associated with local reductions in livestock pressure. In these areas, there has been a large decline in sheep densities because of a fall in the price of sheep products associated with international market restrictions (Montossi et al. 2013). These reductions in sheep numbers resulted in lower herbivory pressure in rocky outcrops and hilly areas where replacement of sheep by cattle is not possible. This release of topdown control by herbivores is likely driving the expansion of forests observed in these regions. Rocky outcrops may have also facilitated tree establishment by protecting tree seedlings from browsing (Müller et al. 2012, Gartzia et al. 2014).

Forest cover also increased in areas with high road density. This increase was more pronounced in coastal, urbanized regions. This seemingly unexpected pattern of forest cover expansion in areas of easier human access and urbanization has been reported in other localities across the Campos and Pampas. Trees originally planted for ornamental or productive uses, e.g., as living fences and refuges for livestock, have included invasive exotic tree species, whose expansion into grasslands and native forests is raising significant concern (Carrere 2001, Nebel and Porcile 2006, Chaneton et al. 2012, Müller et al. 2012). Indeed, the spread of exotic species associated with coastal, highly populated regions, has been detected both for animal and plant species in the Campos (Masciadri et al. 2010).

Unexpectedly, we found that forest cover also increased in drier areas. During the study period, precipitation increased by $10-30 \%$ (Instituto Uruguayo de Meterología [INUMET], unpublished data). Increases in rainfall have been associated with increases in forest productivity in Uruguay (Lucas et al. 2017) and, globally, with trends of tree expansion into grasslands and savannas (Naito and Cairns 2011, Ratajczak et al. 2012, Stevens et al. 2017). The increase in precipitation has likely favored tree growth in Uruguay particularly in the drier regions of the country where its relative impact was likely higher.

We did not detect a significant role of fire in preventing forest expansion. A positive feedback between grass fuel and fire, resulting in open landscapes, has been found to determine the extent of grasslands, savannas, and forests as alternative states in regions with intermediate rainfall levels $(1000-2000 \mathrm{~mm})$ to which our study region largely belongs (Hirota et al. 2011, Staver et al. 2011). However, in the Uruguayan Campos, fire frequency is particularly low (Di Bella et al. 2006), which is likely a result of the very high livestock densities that can consume grass fuel and reduce fire connectivity (Bernardi et al. 2016b). High herbivory can replace fire as a determining driver of alternative tree cover states (Archibald et al. 2005, Archibald and Hempson 2016, 
Fig. 3. Forest cover change and drivers in regions below (green) and above (red) median agricultural cover. (a) Census divisions of Uruguay were grouped into seven edapho-topographic regions that where classified into two categories. Bottom panels: Generalized linear models of forest cover change (\%) between 1966 and 2011 for regions below and above the median agricultural cover. (b-f) Partial plots presented to highlight the individual effects of predictors (Sibly et al. 2012). LU, livestock units; prec., precipitation.

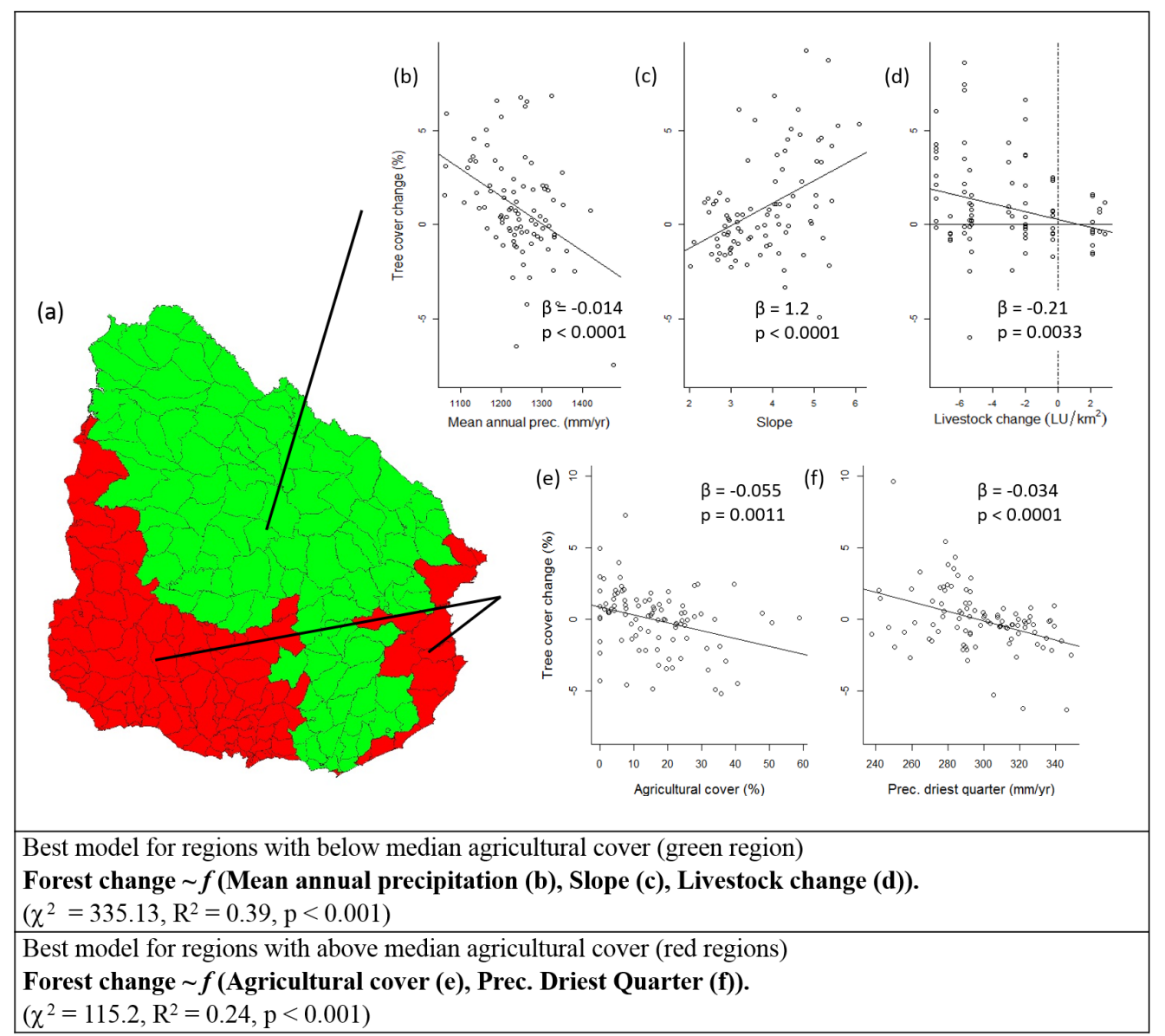

Dantas et al. 2016, Staal et al. 2018, Bernardi et al. 2019). Future assessments of potential forest expansion into grasslands would entail studying how the interaction with fire under different grazing regimes could affect vegetation structure and ecological functions.

Our findings suggest that changes in forest cover in Uruguay can be explained by the interplay of livestock densities and land uses mediated by local climatic, topographic, and soil conditions. Expansions of agriculture and reductions of livestock have locally caused contractions and expansions of forest, respectively, in different parts of the country. These changes in forest cover have probably had a wide range of implications for ecosystem functions and ecological services. For example, tree expansion in grasslands and savannas can impact livestock production either positively (Bernardi et al. 2016a) or negatively (Anadón et al. 2014), alter biodiversity (Overbeck et al. 2007, Veldman et al. 2015), and change carbon cycles and soil properties (Piñeiro et al. 2006, Eclesia et al. 2016, Andriollo et al. 2017), also affecting the composition and functioning of aquatic ecosystems (Roberts et al. 2012). Changes in these ecological services have major implications for nature and society, and they are also differently valued and perceived by social groups (Holmgren and Scheffer 2017).

\section{CONCLUSIONS}

Ecosystems can be strong determinants of the social and economic characteristics of societies. In turn, societies can shape ecosystems through economic and social activities. In particular, by altering disturbance regimes, land use changes can have major impacts on these coupled social-ecological systems. We found that under the current changing climate, livestock and agriculture are counteracting forces that prevent forest expansion in subtropical South America, and that changes in land use intensity and agricultural practices can facilitate transitions between grasslands and forests. Our analysis also highlights the need to take into account medium-scale biogeographic factors that broadly determine the main land use drivers to design better management responses. These results can help to determine potential impacts of forest cover change over time on the diverse range of ecosystem functions and services on which societies depend. 
Responses to this article can be read online at:

http://www.ecologyandsociety.org/issues/responses. $\mathrm{php/10688}$

\begin{abstract}
Acknowledgments:
We would like to thank the Ministerio de Vivienda, Ordenamiento Territorial y Medio Ambiente (MVOTMA) and the Ministerio de Ganadería Agricultura y Pesca (MGAP) for data on land cover and environmental variables, and Lucía Bartesaghi for the digital maps. This research was partially funded by the Agencia Nacional de Investigación e Innovación del Uruguay (ANII). We thank the anonymous reviewers for their constructive comments.
\end{abstract}

\section{LITERATURE CITED}

Aleman, J. C., O. Blarquez, and C. A. Staver. 2016. Land-use change outweighs projected effects of changing rainfall on tree cover in sub-Saharan Africa. Global Change Biology 22:3013-3025. https://doi.org/10.1111/gcb.13299

Anadón, J. D., O. E. Sala, B. L. Turner II, and E. M. Bennett. 2014. Effect of woody-plant encroachment on livestock production in North and South America. Proceedings of the National Academy of Sciences of the United States of America 111:12948-12953. https://doi.org/10.1073/pnas.1320585111

Andriollo, D. D., C. G. Redin, J. M. Reichert, and L. S. da Silva. 2017. Soil carbon isotope ratios in forest-grassland toposequences to identify vegetation changes in southern Brazilian grasslands. CATENA 159:126-135. https://doi.org/10.1016/j.catena.2017.08.012

Archibald, S., W. J. Bond, W. D. Stock, and D. H. K. Fairbanks. 2005. Shaping the landscape: fire-grazer interactions in an African savanna. Ecological Applications 15:96-109. https://doi. org/10.1890/03-5210

Archibald, S., and G. P. Hempson. 2016. Competing consumers: contrasting the patterns and impacts of fire and mammalian herbivory in Africa. Philosophical Transactions of the Royal Society B: Biological Sciences 371:20150309. https://doi. org/10.1098/rstb.2015.0309

Baldi, G., and J. M. Paruelo. 2008. Land-use and land cover dynamics in South American temperate grasslands. Ecology and Society 13(2):6. https://doi.org/10.5751/ES-02481-130206

Behling, H., V. D. Pillar, S. C. Müller, and G. E. Overbeck. 2007. Late-Holocene fire history in a forest-grassland mosaic in southern Brasil: implications for conservation. Applied Vegetation Science 10:81-90. https://doi.org/10.1111/j.1654-109X.2007. tb00506.x

Berkes, F., C. Folke, and J. Colding. 2000. Linking social and ecological systems: management practices and social mechanisms for building resilience. Cambridge University Press, Cambridge, UK.

Bernardi, R. E., I. K. de Jonge, and M. Holmgren. 2016a. Trees improve forage quality and abundance in South American subtropical grasslands. Agriculture, Ecosystems \& Environment 232:227-231. https://doi.org/10.1016/j.agee.2016.08.003
Bernardi, R. E., M. Holmgren, M. Arim, and M. Scheffer. $2016 b$. Why are forests so scarce in subtropical South America? The shaping roles of climate, fire and livestock. Forest Ecology and Management 363:212-217. https://doi.org/10.1016/j.foreco.2015.12.032

Bernardi, R. E., A. Staal, C. Xu, M. Scheffer, and M. Holmgren. 2019. Livestock herbivory shapes fire regimes and vegetation structure across the global tropics. Ecosystems, in press. https:// doi.org/10.1007/s10021-019-00349-X

Blanco, C. C., S. Scheiter, E. Sosinski, A. Fidelis, M. Anand, and V. D. Pillar. 2014. Feedbacks between vegetation and disturbance processes promote long-term persistence of forest-grassland mosaics in south Brazil. Ecological Modelling 291:224-232. https://doi.org/10.1016/j.ecolmodel.2014.07.024

Boletta, P. E., A. C. Ravelo, A. M. Planchuelo, and M. Grilli. 2006. Assessing deforestation in the Argentine Chaco. Forest Ecology and Management 228:108-114. https://doi.org/10.1016/j. foreco.2006.02.045

Bond, W. J. 2008. What limits trees in $\mathrm{C}_{4}$ grasslands and savannas? Annual Review of Ecology, Evolution, and Systematics 39:641-659. https://doi.org/10.1146/annurev.ecolsys.39.110707.173411

Brazeiro, A. 2015. Eco-regiones del Uruguay: biodiversidad, presiones y conservación. Aportes a la Estrategia Nacional de Biodiversidad. Facultad de Ciencias, Universidad de la República, Montevideo, Uruguay.

Brazeiro, A., P. Brussa, and C. Toranza. 2018. Interacciones complejas mediadas por el ganado controlan la dinámica del ecotono bosque-pastizal en paisajes serranos de Uruguay. Ecosistemas 27:14-23.

Brown, J. R., and J. Carter. 1998. Spatial and temporal patterns of exotic shrub invasion in an Australian tropical grassland. Landscape Ecology 13:93-102. https://doi.org/10.1023/A:1007939203931

Brussa, C., and I. Grela. 2007. Flora arbórea del Uruguay: Con énfasis en las especies de Rivera y Tacuarembó. Cofusa, Montevideo, Uruguay.

Cai, X., Z. Wu, and J. Cheng. 2013. Using kernel density estimation to assess the spatial pattern of road density and its impact on landscape fragmentation. International Journal of Geographical Information Science 27:222-230. https://doi. org/10.1080/13658816.2012.663918

Carrere, R. 2001. Monte Indígena: Mucho Más que un Conjunto de Árboles. Ediciones de Brecha, Montevideo, Uruguay.

Chaneton, E. J., N. Mazía, W. B. Batista, A. G. Rolhauser, and C. M. Ghersa. 2012. Woody plant invasions in Pampa grasslands: a biogeographical and community assembly perspective. Pages 115-144 in R. W. Myster, editor. Ecotones between forest and grassland. Springer, New York, New York, USA. https://doi. org/10.1007/978-1-4614-3797-0 5

Dantas, V. d. L., M. Hirota, R. S. Oliveira, and J. G. Pausas. 2016. Disturbance maintains alternative biome states. Ecology Letters 19:12-19. https://doi.org/10.1111/ele.12537

Darwin, C. 1890. The voyage of the Beagle. John Murray, London, UK. 
del Puerto, L., R. Bracco, H. Inda, O. Gutiérrez, D. Panario, and F. García-Rodríguez. 2013. Assessing links between late Holocene climate change and paleolimnological development of Peña Lagoon using opal phytoliths, physical, and geochemical proxies. Quaternary International 287:89-100. https://doi.org/10.1016/j. quaint.2011.11.026

Di Bella, C. M., E. G. Jobbágy, J. M. Paruelo, and S. Pinnock. 2006. Continental fire density patterns in South America. Global Ecology and Biogeography 15:192-199. https://doi.org/10.1111/ j.1466-822X.2006.00225.X

Duran, A. 1987. La Cartografía de Suelos CONEAT y sus Posibilidades de Utilización. Facultad de Agronomía, Universidad de la República, Montevideo, Uruguay.

Eclesia, R. P., E. G. Jobbagy, R. B. Jackson, M. Rizzotto, and G. Piñeiro. 2016. Stabilization of new carbon inputs rather than old carbon decomposition determines soil organic carbon shifts following woody or herbaceous vegetation transitions. Plant and Soil 409:99-116. https://doi.org/10.1007/s11104-016-2951-9

Etchebarne, V., and A. Brazeiro. 2016. Effects of livestock exclusion in forests of Uruguay: soil condition and tree regeneration. Forest Ecology and Management 362:120-129. https://doi.org/10.1016/j.foreco.2015.11.042

Foley, J. A., R. DeFries, G. P. Asner, C. Barford, G. Bonan, S. R. Carpenter, F. S. Chapin, M. T. Coe, G. C. Daily, H. K. Gibbs, J. H. Helkowski, T. Holloway, E. A. Howard, C. J. Kucharik, C. Monfreda, J. A. Patz, I. C. Prentice, N. Ramankutty, and P. K. Snyder. 2005. Global consequences of land use. Science 309:570-574. https://doi.org/10.1126/science.1111772

Gartzia, M., C. L. Alados, and F. Pérez-Cabello. 2014. Assessment of the effects of biophysical and anthropogenic factors on woody plant encroachment in dense and sparse mountain grasslands based on remote sensing data. Progress in Physical Geography: Earth and Environment 38:201-217. https://doi.org/10.1177/0309133314524429

Gautreau, P. 2010. Rethinking the dynamics of woody vegetation in Uruguayan campos, 1800-2000. Journal of Historical Geography 36:194-204. https://doi.org/10.1016/j.jhg.2009.06.016

Geist, H. J., and E. F. Lambin. 2002. Proximate causes and underlying driving forces of tropical deforestation. Bioscience 52:143-150.

González-Roglich, M., J. J. Swenson, D. Villarreal, E. G. Jobbágy, and R. B. Jackson. 2015. Woody plant-cover dynamics in Argentine savannas from the 1880 s to 2000s: the interplay of encroachment and agriculture conversion at varying scales. Ecosystems 18:481-492. https://doi.org/10.1007/s10021-015-9841-5

Hijmans, R. J., S. E. Cameron, J. L. Parra, P. G. Jones, and A. Jarvis. 2005. Very high resolution interpolated climate surfaces for global land areas. International Journal of Climatology 25:1965-1978. https://doi.org/10.1002/joc. 1276

Hirota, M., M. Holmgren, E. H. Van Nes, and M. Scheffer. 2011. Global resilience of tropical forest and savanna to critical transitions. Science 334:232-235. https://doi.org/10.1126/science.1210657

Holmgren, M., M. Hirota, E. H. van Nes, and M. Scheffer. 2013. Effects of interannual climate variability on tropical tree cover.
Nature Climate Change 3:755-758. https://doi.org/10.1038/ nclimate1906

Holmgren, M., and M. Scheffer. 2017. To tree or not to tree: cultural views from ancient Romans to modern ecologists. Ecosystems 20:62-68. https://doi.org/10.1007/s10021-016-0052-5

Iliffe, J., and R. Lott. 2008. Datums and map projections for remote sensing, GIS, and surveying. Whittles, Caithness, UK.

Jeske-Pieruschka, V., A. Fidelis, R. S. Bergamin, E. Vélez, and H. Behling. 2010. Araucaria forest dynamics in relation to fire frequency in southern Brazil based on fossil and modern pollen data. Review of Palaeobotany and Palynology 160:53-65. https:// doi.org/10.1016/j.revpalbo.2010.01.005

Kramer, H., C. A. Mücher, and G. W. Hazeu. 2011. Historical land use databases: a new layer of information for geographical research. International Journal of Humanities and Arts Computing 5:41-58. https://doi.org/10.3366/ijhac.2011.0020

Lehmann, C. E. R., T. M. Anderson, M. Sankaran, S. I. Higgins, S. Archibald, W. A. Hoffmann, N. P. Hanan, R. J. Williams, R. J. Fensham, J. Felfili, L. B. Hutley, J. Ratnam, J. San Jose, R. Montes, D. Franklin, J. Russell-Smith, C. M. Ryan, G. Durigan, P. Hiernaux, R. Haidar, D. M. J. S. Bowman, and W. J. Bond. 2014. Savanna vegetation-fire-climate relationships differ among continents. Science 343:548-552. https://doi.org/10.1126/science.1247355

Lehner, B., K. Verdin, and A. Jarvis. 2006. HydroSHEDS technical documentation, version 1.0. World Wildlife Fund, Washington, D.C., USA. [online] URL: https://hydrosheds.cr. usgs.gov/hydrosheds techdoc v10.doc

Lucas, C., M. Ceroni, S. Baeza, A. A. Muñoz, and A. Brazeiro. 2017. Sensitivity of subtropical forest and savanna productivity to climate variability in South America, Uruguay. Journal of Vegetation Science 28:192-205. https://doi.org/10.1111/jvs.12475

Masciadri, S., E. Brugnoli, and P. Muniz. 2010. InBUy database of Invasive and Alien Species (IAS) in Uruguay: a useful tool to confront this threat to biodiversity. Biota Neotropica 10:205-213. https://doi.org/10.1590/S1676-06032010000400026

McLeod, A., and C. Xu. 2011. bestglm: best subset GLM. R package version 0.33. R Foundation for Statistical Computing, Vienna, Austria. [online] URL: http://CRAN.R-project.org/ package $=$ bestglm

Millennium Ecosystem Assessment. 2005. Ecosystems and human well-being: synthesis. Island, Washington, D.C., USA.

Ministerio de Ganadería, Agricultura y Pesca (MGAP). 1979. Primera Carta Forestal. Dirección Forestal, Parques y Fauna, MGAP, Montevideo, Uruguay.

Ministerio de Ganadería, Agricultura y Pesca (MGAP). 2011. Censo General Agropecuario (1966-2011). Dirección de Estadísticas Agropecuarias, MGAP, Montevideo, Uruguay. [online] URL: http://www2.mgap.gub.uy/portal/page.aspx?2, diea, diea-principal, O,es, 0 .

Ministerio de Ganadería, Agricultura y Pesca (MGAP). 2012. Cartografía Forestal 2012. Dirección General Forestal, MGAP, Montevideo, Uruguay. 
Ministerio de Vivienda, Ordenamiento Territorial y Medio Ambiente; Ministerio de Ganadería, Agricultura y Pesca; and Food and Agriculture Organization of the United Nations (MVOTMA-MGAP-FAO). 2008. Mapa de cobertura de suelo de Uruguay [Land cover classification system]. MVOTMA-MGAPFAO, Montevideo, Uruguay.

Modernel, P., W. A. H. Rossing, M. Corbeels, S. Dogliotti, V. Picasso, and P. Tittonell. 2016. Land use change and ecosystem service provision in Pampas and Campos grasslands of southern South America. Environmental Research Letters 11:113002. http://doi.org/10.1088/1748-9326/11/11/113002

Molfino, J., and A. Califra. 2001. Agua Disponible de las Tierras del Uruguay. Ministerio de Ganadería, Agricultura y Pesca, Montevideo, Uruguay.

Montossi, F., M. Font-i-Furnols, M. del Campo, R. San Julián, G. Brito, and C. Sañudo. 2013. Sustainable sheep production and consumer preference trends: compatibilities, contradictions, and unresolved dilemmas. Meat Science 95:772-789. https://doi. org/10.1016/j.meatsci.2013.04.048

Müller, S. C., G. E. Overbeck, C. C. Blanco, J. M. de Oliveira, and V. P. Pillar. 2012. South Brazilian forest-grassland ecotones: dynamics affected by climate, disturbance, and woody species traits. Pages 167-187 in R. W. Myster, editor. Ecotones between forest and grassland. Springer, New York, New York, USA. https://doi.org/10.1007/978-1-4614-3797-0 7

Naito, A. T., and D. M. Cairns. 2011. Patterns and processes of global shrub expansion. Progress in Physical Geography: Earth and Environment 35:423-442. https://doi.org/10.1177/0309133311403538

Nebel, J. P., and J. F. Porcile. 2006. La Contaminación del Bosque Nativo por Especies Arbóreas y Arbustivas Exóticas. Ministerio de Ganadería, Agricultura y Pesca, Montevideo, Uruguay.

Overbeck, G. E., S. C. Müller, A. Fidelis, J. Pfadenhauer, V. D. Pillar, C. C. Blanco, I. I. Boldrini, R. Both, and E. D. Forneck. 2007. Brazil's neglected biome: the South Brazilian Campos. Perspectives in Plant Ecology, Evolution and Systematics 9:101-116. https://doi.org/10.1016/j.ppees.2007.07.005

Panario, D. 1988. Geomorfología del Uruguay: propuesta de un marco estructural y un esquema de evolución del modelado del relieve uruguayo. Facultad de Humanidades y Ciencias, Universidad de la República, Montevideo, Uruguay.

Paruelo, J. M., J. P. Guerschman, G. Piñeiro, E. G. Jobbagy, S. R. Verón, G. Baldi, and S. Baeza. 2006. Cambios en el uso de la tierra en Argentina y Uruguay: marcos conceptuales para su análisis. Agrociencia 10:47-61.

Pillar, V. P., and F. Quadros. 1997. Grassland-forest boundaries in southern Brazil. Coenoses 12:119-126.

Piñeiro, G., J. M. Paruelo, and M. Oesterheld. 2006. Potential long-term impacts of livestock introduction on carbon and nitrogen cycling in grasslands of southern South America. Global Change Biology 12:1267-1284. https://doi.org/10.1111/

j.1365-2486.2006.01173.x

Piovano, E. L., D. Ariztegui, F. Córdoba, M. Cioccale, and F. Sylvestre. 2009. Hydrological variability in South America below the Tropic of Capricorn (Pampas and Patagonia, Argentina) during the last 13.0 ka. Pages 323-351 in F. Vimeux, F. Sylvestre, and M. Khodri, editors. Past climate variability in South America and surrounding regions. Springer, Dordrecht, The Netherlands. https://doi.org/10.1007/978-90-481-2672-9_14

Ratajczak, Z., J. B. Nippert, and S. L. Collins. 2012. Woody encroachment decreases diversity across North American grasslands and savannas. Ecology 93:697-703. https://doi. org/10.1890/11-1199.1

Redo, D., T. M. Aide, and M. L. Clark. 2013. Vegetation change in Brazil's dryland ecoregions and the relationship to crop production and environmental factors: Cerrado, Caatinga, and Mato Grosso, 2001-2009. Journal of Land Use Science 8:123-153. https://doi.org/10.1080/1747423X.2012.667448

Ribeiro, M. C., J. P. Metzger, A. C. Martensen, F. J. Ponzoni, and M. M. Hirota. 2009. The Brazilian Atlantic Forest: how much is left, and how is the remaining forest distributed? Implications for conservation. Biological Conservation 142:1141-1153. https://doi. org/10.1016/j.biocon.2009.02.021

Richards, P. D., R. J. Myers, S. M. Swinton, and R. T. Walker. 2012. Exchange rates, soybean supply response, and deforestation in South America. Global Environmental Change 22:454-462. https://doi.org/10.1016/j.gloenvcha.2012.01.004

Roberts, W. M., M. I. Stutter, and P. M. Haygarth. 2012. Phosphorus retention and remobilization in vegetated buffer strips: a review. Journal of Environmental Quality 41:389-399. https://doi.org/10.2134/jeq2010.0543

Roy, D. P., L. Boschetti, C. O. Justice, and J. Ju. 2008. The collection 5 MODIS burned area product_-global evaluation by comparison with the MODIS active fire product. Remote Sensing of Environment 112:3690-3707. https://doi.org/10.1016/j.rse.2008.05.013

Saravia, A., D. César, E. Montes, V. Taranto, and M. Pereira. 2011. Manejo del Rodeo de Cría Sobre Campo Natural. Plan Agropecuario, Ministerio de Ganadería, Agricultura y PescaBID, Montevideo, Uruguay.

Sibly, R. M., J., H. Brown, and A. Kodric-Brown, editors. 2012. Metabolic ecology: a scaling approach. John Wiley and Sons, Chichester, West Sussex, UK. https://doi.org/10.1002/9781119968535

Soriano, A. 1992. Río de la Plata grasslands. Pages 367-407 in R. T. Coupland, editor. Ecosystems of the world. Elsevier, Amsterdam, The Netherlands.

Staal, A., E. H. van Nes, S. Hantson, M. Holmgren, S. C. Dekker, S. Pueyo, C. Xu, and M. Scheffer. 2018. Resilience of tropical tree cover: the roles of climate, fire, and herbivory. Global Change Biology 24:5096-5109. https://doi.org/10.1111/gcb.14408

Staver, A. C., S. Archibald, and S. A. Levin. 2011. The global extent and determinants of savanna and forest as alternative biome states. Science 334:230-232. https://doi.org/10.1126/ science. 1210465

Stevens, N., C. E. R. Lehmann, B. P. Murphy, and G. Durigan. 2017. Savanna woody encroachment is widespread across three continents. Global Change Biology 23:235-244. https://doi. org/10.1111/gcb.13409

Vega, E., G. Baldi, E. G. Jobbágy, and J. Paruelo. 2009. Land use change patterns in the Río de la Plata grasslands: the influence 
of phytogeographic and political boundaries. Agriculture, Ecosystems \& Environment 134:287-292. https://doi.org/10.1016/ j.agee.2009.07.011

Veldman, J. W., E. Buisson, G. Durigan, G. W. Fernandes, S. Le Stradic, G. Mahy, D. Negreiros, G. E. Overbeck, R. G. Veldman, N. P. Zaloumis, F. E. Putz, and W. J. Bond. 2015. Toward an oldgrowth concept for grasslands, savannas, and woodlands. Frontiers in Ecology and the Environment 13:154-162. https://doi. org/10.1890/140270

Von Humboldt, A., and A. Bonpland. 2009/1807. Essay on the geography of plants. [Original work published in 1807.] University of Chicago Press, Chicago, Illinois, USA.

Zhang, D. 2018. rsq: R-squared and related measures. $\mathrm{R}$ Foundation for Statistical Computing, Vienna, Austria. [online] URL: https://cran.r-project.org/web/packages/rsq/ 
Appendix 1. Supplementary information

Table A1.1: Environmental and socio-economic variables used in statistical models Table A1.2: Best models and selection criteria.

Table A1.3: Relative $\mathrm{R}^{2}$ of variables. 
Table A1.1. Environmental and socio-economic variables used in statistical models.

\begin{tabular}{|c|c|c|c|c|c|}
\hline Response Variables & Units & Source & Resolution & Year & Reference \\
\hline Forest change & $\%$ & $\begin{array}{l}\text { Forest cartography } 2011 \\
\text { Forest cartography } 1966-67\end{array}$ & $30-250 \mathrm{~m}$ & $1966-2011$ & $\begin{array}{l}(\text { MGAP 2012) } \\
(\text { MGAP 1979) }\end{array}$ \\
\hline \multicolumn{6}{|l|}{ Independent Variables } \\
\hline Mean annual precipitation & $\mathrm{mm} /$ year & \multirow[t]{5}{*}{ WorldClim } & \multirow[t]{5}{*}{$1 \mathrm{~km}$} & \multirow{5}{*}{$\begin{array}{l}\text { Average } \\
1950-2000\end{array}$} & \multirow[t]{5}{*}{ (Hijmans et al. 2005) } \\
\hline Mean annual temperature & ${ }^{\circ} \mathrm{C}$ & & & & \\
\hline $\begin{array}{l}\text { Coefficient of variation of } \\
\text { precipitation }\end{array}$ & - & & & & \\
\hline Precipitation driest quarter & $\mathrm{mm} /$ year & & & & \\
\hline Temperature hottest quarter & ${ }^{\circ} \mathrm{C}$ & & & & \\
\hline Soil productivity index - CONEAT & - & MGAP & $\sim 20 \mathrm{~m}$ & 1976 & (Duran 1987) \\
\hline Soil water holding capacity index & $\mathrm{mm}$ & MGAP & $\sim 500 \mathrm{~m}$ & 1976 & (Molfino and Califra 2001) \\
\hline Altitude & $\mathrm{m}$ & MGAP & $90 \mathrm{~m}$ & & http://www.snia.gub.uy \\
\hline Slope & - & MGAP & $90 \mathrm{~m}$ & & http://www.snia.gub.uy \\
\hline River density & $\mathrm{m} / \mathrm{km}^{2}$ & HYDROSHED & 15 arc-minutes & 2000 & (Lehner et al. 2006) \\
\hline Road Density & $\mathrm{m} / \mathrm{km}^{2}$ & MTOP & $\sim 20 \mathrm{~m}$ & 2000 & www.snia.gub.uy \\
\hline Agricultural cover & $\%$ & MVOTMA & $30 \mathrm{~m}$ & 2008 & (MVOTMA-MGAP-FAO 2008) \\
\hline Livestock density & $\mathrm{LU} / \mathrm{km}^{2}$ & MGAP & Census unit & 2010 & $\begin{array}{l}\text { http://www2.mgap.gub.uy/portal/page.a } \\
\text { spx?2,diea,diea-principal,O,es,0 }\end{array}$ \\
\hline Livestock density change & $\mathrm{LU} / \mathrm{km}^{2}$ & MGAP & Department & $1960-2010$ & National Agricultural Census \\
\hline Fire frequency & \# & $\begin{array}{l}\text { MODIS MCD445A1 Burned } \\
\text { Areas Monthly product }\end{array}$ & $30 \mathrm{~m}$ & 2000 & (Roy et al. 2008). \\
\hline
\end{tabular}


Table A1.2, Best models and selection criteria. Best models obtained with the function Bestglm in R (McLeod and Xu 2011). Model selection was done by AIC and tested by Cross Validation. Best alternative models (not retained by the selection criteria) are shown. Moran's I values were calculated to assess spatial autocorrelation.

\begin{tabular}{|c|c|c|c|}
\hline $\begin{array}{l}\text { Best models and selection criteria. } \\
\text { Response variable: Forest Change } 1966-2011 \text { (\%) } \\
\text { Predictor variables: See Table A1.1 }\end{array}$ & AIC & CV & $\begin{array}{l}\text { Moran's.I } \\
\text { (residuals) }\end{array}$ \\
\hline \multicolumn{4}{|l|}{ Uruguay } \\
\hline$f$ (Agricultural cover, Road Dens., Precip. driest quarter, Slope) & 847.8 & 6.5 & 0.08 \\
\hline$f$ (Agricultural cover, Precip. driest quarter, Slope, Altitude) & 849.2 & 6.6 & \\
\hline$f$ (Agricultural cover, Precip. driest quarter, Slope, Cattle/sheep ratio) & 849.2 & 6.7 & \\
\hline$f$ (Agricultural cover, Precip. driest quarter, Slope) & 851.1 & 6.6 & \\
\hline$f$ (Agricultural cover, Road Dens., Precip. driest quarter) & 852.9 & 6.5 & \\
\hline \multicolumn{4}{|l|}{ Above median agricultural cover } \\
\hline$f$ (Agricultural cover, Precip. driest quarter) & 406.1 & 4.8 & 0.1 \\
\hline$f$ (Agricultural cover, Precip. driest quarter, Cattle/sheep ratio) & 406.8 & 5.0 & \\
\hline$f$ (Agricultural cover, Precip. driest quarter, Livestock change) & 407.2 & 4.9 & \\
\hline$f$ (Agricultural cover, Precip. driest quarter, River Density) & 407.5 & 5.3 & \\
\hline$f$ (Agricultural cover, Precip. driest quarter, Road Dens.) & 417.33 & 5.0 & \\
\hline \multicolumn{4}{|l|}{ Below median agricultural cover } \\
\hline$f$ (Mean annual prec., Slope, Livestock change) & 419.6 & 7.3 & 0.05 \\
\hline$f$ (MAP, Slope, Soil water hold. capacity, Livestock change) & 418.5 & 8.2 & \\
\hline$f$ (Agricultural cover, Mean annual prec., Slope, Livestock change) & 418.9 & 7.9 & \\
\hline$f$ (MAP, Slope, Soil water hold. capacity) & 420.5 & 7.6 & \\
\hline$f$ (Mean annual prec., Slope) & 422.3 & 7.3 & \\
\hline
\end{tabular}


Table A1.3. Relative $\mathrm{R}^{2}$ of variables in the best models.

\begin{tabular}{|l|l|}
\hline \multicolumn{2}{|l|}{ Relative $\mathbf{R}^{\mathbf{2}}$ of variables in best models } \\
\hline \multicolumn{2}{|l|}{ Uruguay } \\
\hline Precipitation driest quarter & 0.09 \\
\hline Agricultural cover \% & 0.06 \\
\hline Slope & 0.04 \\
\hline Road Density & 0.03 \\
\hline Above median agricultural cover \\
\hline Precipitation driest quarter & 0.16 \\
\hline Agricultural cover \% & 0.11 \\
\hline Below median agricultural cover & \\
\hline Slope & 0.17 \\
\hline Mean annual precipitation & 0.13 \\
\hline Livestock density & 0.05 \\
\hline
\end{tabular}




\section{LITERATURE CITED IN ANNEX I}

Duran, A. 1987. La Cartografía de Suelos CONEAT y sus Posibilidades de Utilización. Facultad de Agronomía, Universidad de la República, Montevideo, Uruguay.

Hijmans, R. J., S. E. Cameron, J. L. Parra, P. G. Jones, and A. Jarvis. 2005. Very high resolution interpolated climate surfaces for global land areas. International Journal of Climatology 25:19651978. https://doi.org/10.1002/joc.1276

Lehner, B., K. Verdin, and A. Jarvis. 2006. HydroSHEDS technical documentation, v. 1.0. World Wildlife Fund, Washington, D.C., USA. [online] URL: www.hydrosheds.org

McLeod, A. and C. Xu. 2011. bestgIm: Best Subset GLM. R package version 0.33. URL http://CRAN.Rproject.org/package=bestglm, R Foundation for Statistical Computing, Vienna, Austria.

MGAP. 1979. Primera Carta Forestal. Dirección Forestal, Parques y Fauna. Ministerio de Agricultura y Pesca, Montevideo, Uruguay.

MGAP. 2012. Cartografía Forestal 2012. Dirección General Forestal. Ministerio de Ganadería, Agricultura y Pesca, Montevideo, Uruguay.

Molfino, J., and A. Califra. 2001. Agua Disponible de las Tierras del Uruguay. Ministerio de Ganadería, Agricultura y Pesca, Montevideo, Uruguay.

Ministerio de Vivienda, Ordenamiento Territorial y Medio Ambiente; Ministerio de Ganadería, Agricultura y Pesca; and Food and Agriculture Organization of the United Nations (MVOTMA-MGAPFAO). 2008. Mapa de cobertura de suelo de Uruguay [Land cover classification system]. MVOTMAMGAP-FAO, Montevideo, Uruguay

Roy, D. P., L. Boschetti, C. O. Justice, and J. Ju. 2008. The collection 5 MODIS burned area productglobal evaluation by comparison with the MODIS active fire product. Remote Sensing of Environment 112:3690-3707. https://doi.org/10.1016/j.rse.2008.05.013 